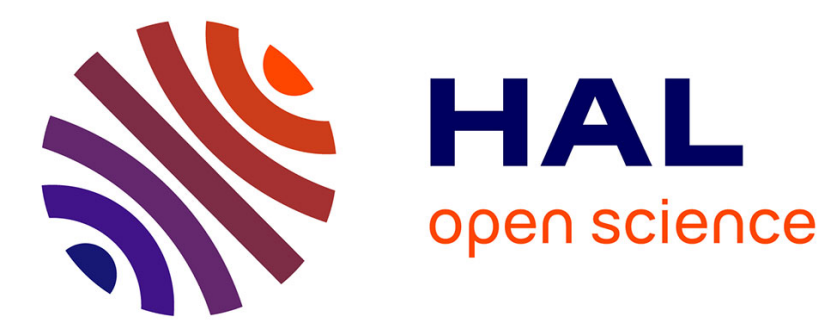

\title{
Ferricrete biochemical degradation on the rainforest-savannas boundary of Central African Republic
}

Anicet Beauvais

\section{- To cite this version:}

Anicet Beauvais. Ferricrete biochemical degradation on the rainforest-savannas boundary of Central African Republic. Geoderma, 2009, 150, pp.379-388. 10.1016/j.geoderma.2009.02.023 . hal01097326

\section{HAL Id: hal-01097326 \\ https://hal.science/hal-01097326}

Submitted on 23 Dec 2016

HAL is a multi-disciplinary open access archive for the deposit and dissemination of scientific research documents, whether they are published or not. The documents may come from teaching and research institutions in France or abroad, or from public or private research centers.
L'archive ouverte pluridisciplinaire HAL, est destinée au dépôt et à la diffusion de documents scientifiques de niveau recherche, publiés ou non, émanant des établissements d'enseignement et de recherche français ou étrangers, des laboratoires publics ou privés. 
3

4 5

6

10 11 12 13 14 15 16 17 18

19 20 21 22 23 24 25 26 27 28 29 30 31 32 33 34 35

\section{Ferricrete biochemical degradation on the rainforest-savannas}

\section{boundary of Central African Republic}

\author{
Anicet Beauvais \\ CEREGE (Centre Européen de Recherche et d'Enseignement des Géosciences de \\ l'Environnement), Aix-Marseille Université, CNRS, INSU, IRD, CdF, Europôle \\ Méditerranéen de l'Arbois, BP 80, 13545 Aix-en-Provence Cedex 4 France
}

beauvais@cerege.fr (tel./fax: (33) 4429717 73/4 4297 15 95) 


\section{Abstract}

39

40

41

42

61
In southeastern Central African Republic the lateritic weathering mantles are capped by two to five meters thick ferricretes, which previously formed under a seasonal tropical climate. The actual humid tropical climatic conditions result in the biophysical disaggregation of the ferricretes everywhere the forest develop that lead to a soil formation composed of ferricrete relicts and ferruginous nodules embedded in a soft bioturbated micro-aggregated clay-ferruginous matrix. The potential effect of the biological activity (e.g., termites) on the soil and vegetation dynamics and therefore on the evolution of the previous consolidated ferricrete is discussed. Following its mechanical disaggregation by the forest tree roots, the ferricrete underwent a chemical degradation under the combined effect of hydration and redox conditions, which result from the biodegradation and oxidation of the organic matter. The transformation of the ferricrete into a soft bioturbated micro-aggregated clay-ferruginous soil matrix implies the hematite dissolution, and the kaolinite transformation into gibbsite, which may characterize a late "bauxitization" (secondary gibbsitization of kaolinite) of previous ferricrete profiles linked to a late Quaternary environmental (climate and vegetation) change. However, the geochemical and mineralogical pattern of the matrix not only reflects the geochemistry of the parental ferricrete but also depends on the physical transfers of quartz and heavy minerals from the lower horizons of the profile. Hence, the use of geochemical indexes such as $\mathrm{Ti}$ and/or $\mathrm{Zr}$ for mass balance calculations in the lateritic weathering profiles is precluded because these supposedly inert chemical elements are not simply accumulated by in situ chemical weathering process.

Keywords: Biochemical weathering; Ferricrete; Bauxitization; Termites; Central African Republic

Beauvais, 2008 


\section{Introduction}

67

Long term rock chemical weathering throughout the intertropical zone led to the formation of several tens meters of lateritic weathering profiles, many being capped by two to ten meters thick ferricretes. From the bottom to the top, a ferruginous lateritic weathering profile is generally composed of a saprolite, a mottled clay horizon, a soft ferricrete and/or a soft nodular horizon and a ferricrete (Nahon, 1986; Tardy, 1997; Beauvais, 1999). The ferricretes developed under a seasonal tropical climate and represent the ultimate stage of the ferruginization process that started earlier in the mottled clay horizon (Tardy and Nahon, 1985; Nahon, 1986, 1991; Thomas, 1994; Tardy, 1997; Beauvais, 1999). With the increasing ferruginization, the geochemical signature of parent rocks is progressively blurred until nearly complete deletion in the ferricrete (Tardy et al., 1988; Tardy, 1997). The large intertropical areas over which the ferricretes actually outcrop suggest paleoclimatic changes towards drier conditions (Tardy and Roquin, 1998) that led to the degradation of the vegetation cover with a consecutive mechanical erosion of the upper leached horizon, which previously overlay the buried ferricrete (Büdel, 1982; Millot, 1983; Butt, 1987).

However, the exposed ferricretes may disaggregate and geochemically degrade under the wet and warm climatic conditions characterizing the rainforest environments (Novikoff, 1974; Nahon et al., 1989; Thomas, 1994; Tardy, 1997). The degradation of previously consolidated ferricretes implies a complete reorganization of the uppermost part of the profile under the effects of biological activity and almost permanent moisture. Therefore, the disaggregated ferricrete is progressively transformed into a soil containing blocks and debris of ferricrete of various sizes including centimeter size ferruginous nodules embedded in a bioturbated micro-aggregated clay ferruginous matrix similar to that of many red ferruginous tropical soils. Such a transformation is 
91 investigated (1) by comparing the main geochemical outlines of an undisturbed

92 ferricrete profile and a disaggregated ferricrete horizon, and (2) by defining the

93 geochemical differentiation pattern of two disaggregated ferricrete horizons at the top of

94 lateritic weathering profiles profile developed upon different parent rocks. The

95 biophysical and geochemical processes involved in the ferricrete degradation are

96 discussed. In particular, the potential role of the biological activity (e.g., termites) on the

97 degradation processes of previous undisturbed ferricrete profiles is approached.

\section{Field description}

100
The study area ("Haut Mbomou") is located in southeastern Central African Republic (CAR) (Fig. 1a). The climate is humid seasonal tropical with a dry season from December to February and a mean annual rainfall of $1600 \mathrm{~mm}$ (Fig. 1a), a mean annual temperature of $25^{\circ} \mathrm{C}$ and a mean annual relative humidity of the air of $80 \%$. The southern part of CAR hosts forests belonging to the Congo-Guinean domain (Sillans, 1958), where Terminalia superba, Albizia zygia, Triplochiton scleroxylon and Celtis sp. are the main identified species (Boulvert, 1986; Beauvais, 1991).

The vegetation of the study area is a mosaic of grass savanna interspersed with patches of dense rain forest. About $79.3 \%$ of the total landsurface of the previous mapped area $\left(545 \mathrm{~km}^{2}\right)$ are covered by grass savanna where consolidated ferricrete is outcropping on plateaus and hillslopes, while the rain forest occupies the remaining $20.7 \%$ where the ferricrete is disaggregated resulting in the formation of dismantled ferricrete soils (Beauvais and Roquin, 1996; Fig. 1b). The extension of forest against savanna in the Mbomou area was dated from the Holocene period using $\mathrm{C}$ isotopic analyses of organic matter in soils and alluvial sediments (Runge, 2002) that also characterize a climatic change towards more humidity. A semi-humid forest with Beauvais, 2008 
117 Anogeissus leiocarpus and Albizia zygia effectively develops around the highest

118 plateaus (10.6\% of the total surface) at a topographic slope gradient change (Fig. 1c),

119 while a Guinean selvage forest with Triplochiton scleroxylon and Celtis sp. occupies

120 relatively incised thalwegs ( $10.1 \%$ of the total surface). A Soudano-Guinean savanna

121 with Daniella oliveri and Terminalia glaucescens alternates with Graminaceae such as

122 Ctenium newtonii and Loudetia annua (Sillans, 1958), where ferricrete effectively

123 outcrops on the plateaus (Boulvert, 1986; Beauvais, 1991).

124 The degradation processes of the ferricrete are investigated on vertical profiles located

125 in the forested transition area between the high plateaus and the bare hillslope (Figs. 1b

126 and 1c), which carry massive or protonodular and protopisolitic ferricretes, respectively,

127 as previously established from a combined geomorphological and petrological study of

128 the main ferricretes in the "Haut-Mbomou" region (Beauvais and Roquin, 1996). In the

129 "Haut-Mbomou" area, the moderate epeirogenesis resulted in insufficient river incision

130 and erosion that did not allow a clear differentiation of stepped lateritic

131 paleolandsurfaces (bauxitic and ferruginous) like those characterizing the West African

132 landscapes (Eschenbrenner and Grandin, 1970, Michel, 1973; Grandin, 1976; see also

133 Beauvais et al., 1999). The long-term (Cenozoic) climatic change gradient was higher in

134 West Africa than in CAR (Tardy and Roquin, 1998). Paleoclimates evolved from humid

135 to dry in West Africa, and from arid to seasonal humid tropical in CAR that led to

136 continuous ferricrete formation during Tertiary (Beauvais, 1991; Beauvais and Colin,

137 1993; Tardy and Roquin, 1998) instead of successive development of bauxite and

138 ferruginous glacis (pediments). However, the high plateaus and hillslopes or low

139 plateaus of the "Haut-Mbomou" could be analogous of the West African intermediary

140 and high glacis landsurfaces, respectively (Boulvert, 1996).

Beauvais, 2008 
141 The "Haut-Mbomou" landscape is also characterized by "mushroom" termite

142 mounds of Cubitermes fungifaber, which are systematically erected on gently sloping

143 surfaces bearing a ferricrete (Fig. 3a), called "lakéré" (Sillans, 1958; Boulvert, 1986).

144 Runge and Lammers (2001) counted five to six hundred termite mounds per hectare for

145 an area of $75,000 \mathrm{~km}^{2}$ (Mbomou plateau) that imply a denudation rate of $0.1 \mathrm{~mm} . \mathrm{ha}^{-}$

$146{ }^{1}$.year ${ }^{-1}$ corresponding to $0.94 \mathrm{t}$. $\mathrm{ha}^{-1} \cdot$ year $^{-1}$ of material removed by termites from the

147 lower weathered horizons (saprolite and mottled clays). This material is therefore

148 available for surface runoff erosion and dispersion over the outcropping ferricretes (Fig.

$1493 \mathrm{~b}$ ) that may favor the forest growth at the expenses of savanna under humid tropical

150 climatic conditions.

\section{Material and analytical techniques}

153

154

155

156

157

158

159

160

161

162

163

164

165

166
The degradation patterns of the ferricrete are studied and analyzed in the uppermost-disaggregated parts ( 1 to $4.5 \mathrm{~m}$ ) of two vertical lateritic weathering profiles (Figs. 2c and 2d) at Guenekoumba and Finzani in southeastern CAR (Figs. 1a). The two vertical profiles are located in the forest fringe (forested hillslope) between the high plateau and the bare hillslope both bearing undisturbed ferricrete profiles (Fig. 1b). The weathering profile of Guenekoumba is developed on amphibole schist (Beauvais and Colin, 1993) while epimetamorphic schist intruded by granite constitutes the parent rocks of the Finzani weathering profile. Based on geological map, the amphibole schist rocks were observed and collected on outcrops and in riverbeds, while the epimetamorphic schist was deduced by the direct observation of saprolites (Beauvais, 1991; Beauvais and Colin, 1993). A typical disaggregated ferricrete horizon is composed of three main components (Fig. $2 b$ to $2 d$ ). A first component corresponds to the disaggregated ferricrete of 1-2 to $3 \mathrm{~m}$ thickness, which is often affected by

Beauvais, 2008 
167 horizontal joints (Fig. 2c and 2d), the edges of which being overlain by lamellar

168 goethitic brown secondary deposits. Decimetric and metric fragments and blocks of

169 ferricrete characterize this sub-horizon. The second component is composed of

170 hematitic ferruginous nodules and clasts of ferricrete of size ranging between 1 and 10

$171 \mathrm{~cm}$. This sub-horizon can also contain some humus in its uppermost part. The nodules

172 are larger at the top than at the base of the horizon. The third component consists of the

173 bioturbated micro-aggregated clay-ferruginous matrix, in which the nodules and clasts

174 of ferricrete are embedded and the biological activity is highly developed (Fig. 2b).

175 Fifty-three samples and sub-samples were collected between 0 and 4.5 meters

176 (Figs. 2c and 2d): thirty-three samples for Guenekoumba (15 ferricrete relicts, 9 nodules

177 and 9 matrices) and twenty samples for Finzani (6 ferricrete relicts, 6 nodules and 7

178 matrices). Subsamples of nodules and matrices were extracted from a same sample.

179 XRD was used to determine the mineral composition of each sample category, i.e.,

180 the quantity of quartz, kaolinite, gibbsite, hematite and goethite. Mineral contents were

181 estimated by measuring characteristic intensity of X-ray peak weighted by a calibration

182 coefficient defined for each mineral, using normative calculations (Mazaltarim, 1989).

183 The estimation error ranges from 1 to $3 \%$. Each sample was therefore defined by five

184 mineralogical variables, corresponding to the estimated contents of kaolinite (Ka),

185 quartz (Q), gibbsite (Gi), goethite (Go), hematite (He), and also by the ratios, RGH

186 equal to $100 *$ goethite/(goethite + hematite), and RKGi equal to $100 *$

187 kaolinite/(gibbsite + kaolinite) as defined by Beauvais and Roquin (1996). Scanning

188 electron microscopy has been also used to define the crystalline morphology of the main mineral phases for each ferricrete degradation component.

190 Spark emission spectrometry has provided chemical composition for major

191 elements, $\mathrm{Si}, \mathrm{Al}, \mathrm{Fe}, \mathrm{Mn}, \mathrm{Mg}, \mathrm{K}, \mathrm{Ti}, \mathrm{P}$. Inductively coupled plasma atomic emission 
192 spectrometry (ICP-AES) was used to dose the trace elements, Sr, Ba, V, Ni, Co, Cr, Zn,

$193 \mathrm{Cu}, \mathrm{Sc}, \mathrm{Y}, \mathrm{Zr}, \mathrm{La}, \mathrm{Ce}, \mathrm{Yb}, \mathrm{Nb}$.

194 Mineralogical and chemical data were statistically analyzed by a principal component

195 analysis (PCA) using StatView F- 4.5 (1995) that allowed differentiation of the main

196 geochemical patterns of each sample category. The eigenvectors are first determined with

197 their associated Eigen values from the correlation matrix, followed here by an application of

198 the orthogonal Varimax rotation procedure (Lebart et al., 1979). The principal components

199 (factorial axes) describe the main differentiation trends in the data set. These independent

200 synthetic variables are characterized by correlation loadings with chemical elements and

201 minerals, as previously applied to tropical soils (Litaor et al., 1989; Donkin and Fey, 1991),

202 bauxitic weathering profiles and ferricretes regional distribution (Boski and Herbosch, 1990;

203 Roquin et al., 1990; Beauvais and Roquin, 1996). Within each factor, the correlation loadings

204 ranging from -0.4 to 0.4 were considered as non-significant regarding to the samples number.

205 The projection of samples on factor score diagrams highlights the differentiation patterns

206 within and between each samples category, allowing discussion of the geochemical and

207 mineralogical evolution induced by the development of the weathering and ferruginization

208 and/or the ferricrete degradation process.

209

210

\section{Results and discussion}

211

\subsection{Petrographical outlines of the ferricrete degradation}

The formation processes of undisturbed lateritic weathering profiles (Fig. 2a) were

215 previously studied (Beauvais and Colin, 1993; Beauvais, 1999). The present study

216 focuses on the uppermost part (ferricrete) of such profiles, which is apparently

217 disaggregated and degraded under the forest (Fig. 2b). The ferruginous nodules of such 
218 horizon have the same petrographical fabric as the ferricrete. However, many nodules

219 exhibit peripheral goethite brown rims (Fig. 4a) composed of many thin crystals, which

220 develop perpendicular to the edge of the hematitic core of the nodules (Fig. 4b). Other

221 nodules previously composed of hematite and kaolinite (Beauvais, 1999) show gibbsite

222 crystals formed at the expense of the kaolinite (Fig. 5a). Secondary gibbsite crystals of

$22310 \mu \mathrm{m}$ size are also observed within vacuolar voids of 20 to $50 \mu \mathrm{m}$ sizes (Fig. 5b). The

224 bioturbated micro-aggregated clay ferruginous matrix is also characterized by the

225 formation of smaller size $(2 \mu \mathrm{m})$ gibbsite crystals within the vacuolar and tubular

226 porosity (Fig. 6a and 6b). This gibbsite is not inherited but comes from the process of

227 ferricrete transformation, contemporaneously with the secondary gibbsite forming in the

228 kaolinitic saprolite of undisturbed profiles (Beauvais and Colin, 1993; Beauvais, 1999).

229 The degradation matrix also contains small size $(10 \mu \mathrm{m})$ quartz gains (Fig. 6c and 6d),

230 which may be mechanically transferred from other parts of the profile through the

231 termite activity (Eschenbrenner, 1986; Tardy, 1997; Thomas, 1994).

232

\subsection{Undisturbed versus disaggregated ferricrete profile}

A comparison between a previously studied undisturbed lateritic weathering profile with

236 consolidated ferricrete (Beauvais and Colin, 1993) and the disaggregated ferricrete horizon of

237 an adjacent profile in the Guenekoumba site (Figs. 2a, 2b and 2c) allows differentiation

238 between the advancing ferruginization and the geochemical degradation of ferricretes. The

239 development of the undisturbed weathering profile is a function of two complementary

240 processes: saprolitization and ferruginization (Beauvais and Colin, 1993), during which iron

241 first increases by relative accumulation (saprolitization) and secondly by absolute

242 accumulation that leads to the ferricrete development (Beauvais, 1999). These processes are

243 characterized by analyzing the behavior of Fe against Sc (Brown et al., 2003). Except for the

Beauvais, 2008 
244 absolute Fe depletion due to local reduction process in the saprolite, Fe and Sc increase in 245 same proportions (relative Fe accumulation) during the first stage of in situ rock chemical

246 weathering. However, Fe and Sc show a more contrasted behavior during the ferruginization

247 process driven by oxidation processes that lead to the development of the soft nodular and

248 ferricrete horizons by absolute Fe accumulation (Fig. 7a).

249 The ferricrete geochemical degradation first leads to a decrease of Sc compared to

250 the ferricrete of the undisturbed profile, then to a decrease of Fe with approximately

251 constant Sc (Fig. 7a). The nodules of the disaggregated horizon are richer in Fe than the

252 nodules of the soft nodular layer underlying the ferricrete of the undisturbed profile.

253 The first effectively derive from the physical disaggregation and geochemical

254 degradation of the ferricrete, whereas the second are advanced ferruginized forms of

255 mottled clays (Tardy and Nahon, 1985; Nahon, 1986, 1991; Tardy, 1997). The matrices

256 of the disaggregated ferricrete horizon show less Sc content than the saprolite and the

257 mottled clays of the undisturbed ferricrete profile (Fig. 7a). These matrices are also

258 enriched in Zr and Si (Quartz), and show similar Ti contents as the saprolite and mottled

259 clays of the undisturbed ferricrete profile (Figs. 7b-d). Ti and $\mathrm{Zr}$ are not correlated in

260 the undisturbed profile while they co-vary in the disaggregated ferricrete horizon (Fig.

261 7d). They may relatively enrich from the ferricrete degradation or absolutely

262 accumulate by some mechanical transfer from other parts of the profile.

263 A principal component analysis of the geochemical and mineralogical data of the

264 undisturbed and disaggregated profiles yields four factorial axes describing $75.2 \%$ of

265 the total variance (Table 1$)$. The first factorial axis $(37.3 \%$ of the total variance)

266 discriminates the saprolitization with its residual parent rock mineralogical inheritage

267 (quartz + heavy minerals) from the advancing ferruginization (hematite and goethite)

268 processes (Fig. 8). The second factorial axis (23.6\% of the total variance) characterizes 
269 the ferricrete degradation by discriminating the clay-ferruginous matrices from the

270 ferricrete relicts and nodules (Fig. 8). The figure 8 also shows the differentiation of the

271 degradation matrices from the saprolite and mottled clays of the undisturbed ferricrete

272 profile. Compared to the parental ferricretes the degradation matrices are enriched in

273 quartz, gibbsite and heavy minerals and impoverished in iron, hematite and kaolinite.

274 The third factorial axis ( $7.2 \%$ of the total variance) clearly described the transformation

275 of kaolinite into gibbsite in the undisturbed ferricrete profile (Beauvais and Colin, 1993)

276 but also in the degradation matrices (Table 1 and Figs. 6a-b) that could characterize the

277 late "bauxitization" (i.e., secondary gibbsitization according to Tardy, 1997) of the

278 previous ferricrete profiles. This "bauxitization" may result from the development of

279 the forest at the expenses of savanna linked to a more humid climate since the Holocene

280 (7.5 to $7 \mathrm{ka})$ (Runge, 2002). The fourth factorial axis (7.1\% of the total variance)

281 collates $\mathrm{Ce}, \mathrm{Ba}, \mathrm{Sr}$ and $\mathrm{La}$, which reflect some parent rock geochemical inheritance

282 (Table 1). Secondary minerals such as florencite may also form as it was suggested in

283 similar lateritic weathering profiles of Cameroon (Braun et al., 1990). Cerianite (Ce-

284 oxide) was also identified at the bottom of the soft nodular horizon in the undisturbed

285 ferricrete profile of Guenekoumba (Beauvais and Colin, 1993).

286

287

\subsection{Geochemical differentiation pattern of two disaggregated ferricrete horizons}

The average geochemical and mineralogical compositions of each ferricrete

290 degradation components (ferricrete elements, nodules and soft matrices) are given in the

291 table 2. The degradation components of the Guenekoumba profile are, on the average,

292 less rich in silica, alumina, $\mathrm{MgO}$, and $\mathrm{K}_{2} \mathrm{O}$ but richer in $\mathrm{Fe}_{2} \mathrm{O}_{3}, \mathrm{Mn}_{3} \mathrm{O}_{4}, \mathrm{TiO}_{2}$ and $\mathrm{P}_{2} \mathrm{O}_{5}$

293 than those of the Finzani profile. These geochemical differences reflect differences of

294 parent rocks, which are also emphasized by differences in $\mathrm{V}, \mathrm{Cr}, \mathrm{Cu}, \mathrm{Zn}, \mathrm{Y}, \mathrm{Ba}, \mathrm{La}$ and

Beauvais, 2008 
295 Ce contents (Table 2). A relatively high amount of $\mathrm{K}_{2} \mathrm{O}$ and $\mathrm{Ba}$ has been noted in the

296 Finzani ferricrete relicts as well as some $\mathrm{Mg}$ (Table 2) that may indicate a relatively

297 quick ferruginization of saprolite still embedding poorly weathered micas prior to the

298 hardening of the ferricrete (Beauvais, 1991, 1999). Therefore, the differences of

299 alumina contents may be explained by the accumulation of relict micas and kaolinite

300 higher in the Finzani profile than in the Guenekoumba profile (Table 2).

301 The geochemical differentiation patterns of each sample category (ferricrete relicts,

302 nodules, and matrix) are also deciphered, by applying a Principal Component Analysis

303 (PCA) to the geochemical and mineralogical data that allows definition of three

304 factorial axes accounting for $76.4 \%$ of the total variance (Table. 3 ). The first factorial

305 axis (44.1\% of the total variance) discriminates the group (ferricrete relicts + the

306 ferruginous nodules) from the embedding clay-ferruginous matrices (Fig. 9). These

307 latter are enriched in quartz (Figs. 6c-d and 10a) and heavy minerals (Fig. 10b) and they

308 are propitious to the development of gibbsite (Figs. 6a-b and 11a), which results from

309 the late weathering of micas and/or from the desilification and hydration of kaolinite

310 (Beauvais and Roquin, 1996). With quartz, the heavy minerals compose the residual

311 mineral phase, which may be relatively enriched by in situ geochemical degradation of

312 ferricrete containing them (Figs. 9 and 10b) or mechanically transferred with the clay-

313 silt materials from other parts of the profile through the termite activity (Tardy and

314 Roquin, 1992). The variation of $\mathrm{Zr}$ content in matrices at constant Fe (Fig. 11b) may

315 also suggest, at least partially, an absolute input of small size zircon. Hence, the

316 common use of $\mathrm{Ti}$ and $\mathrm{Zr}$ for mass balance calculations should be considered with much

317 caution. Zircon may also dissolve in the lateritic geosphere (Colin et al., 1993). Mass

318 balance calculations based on geochemical indexes may be applied for non-perturbed

319 weathering horizons (Beauvais and Colin, 1993) but they are inappropriate for 
320 quantifying the geochemical mass balance transfers in the upper ferruginous horizons

321 that are bioturbated and often rework allochthomous materials (Beauvais et al., 1999).

The geochemical degradation of the ferricrete therefore leads to a release of $\mathrm{Fe}_{2} \mathrm{O}_{3}$,

$\mathrm{Sr}, \mathrm{Ba}, \mathrm{V}$, and $\mathrm{Cr}$, with an accumulation of silica, alumina, $\mathrm{Mn}_{3} \mathrm{O}_{4}, \mathrm{MgO}, \mathrm{K}_{2} \mathrm{O}$ and $\mathrm{TiO}_{2}$ in the matrices, and also, $\mathrm{Ni}, \mathrm{Y}, \mathrm{Zr}, \mathrm{Yb}$ and $\mathrm{Nb}$. The amounts of $\mathrm{P}_{2} \mathrm{O}_{5}$, and $\mathrm{Co}, \mathrm{Zn}, \mathrm{Cu}$,

325 Sc, La, and Ce remain relatively constant (Table 2). The increasing of magnesium and

326 potassium in the matrices of degradation profiles may reflect the occurrence of poorly

327 weathered micas as phengites that is indicated by the negative loading of the second

328 factorial axis (20.9\% of the total variance). Previous geochemical analyses of saprolite and mottled clays of Guenekoumba undisturbed profile revealed similar $\mathrm{Mg}$ and $\mathrm{K}$

330 contents, which related to poorly weathered relict micas optically identified on thin

331 sections (Beauvais and Colin, 1993). The second factorial axis also characterizes the association of goethite with $\mathrm{Cu}, \mathrm{TiO}_{2}, \mathrm{Zn}, \mathrm{P}_{2} \mathrm{O}_{5}, \mathrm{Mn}_{3} \mathrm{O}_{4}$, and $\mathrm{Sc}$ (Table 3), which may indicate the presence of anatase and/or residual ilmenite in the degradation matrices as

334 previously shown in undisturbed weathering profile (Beauvais and Colin, 1993). The

335 factor 2 therefore discriminates the Ti-rich Guenekoumba degradation profile from the

336 Ba-Mg-K rich Finzani degradation profile (Fig. 9) that suggests incomplete micas

337 dissolution in this profile although a part of the kaolinite may derive from their late

338 weathering in the degradation matrices (Table 2$)$. The third factorial axis $(11.4 \%$ of the

339 total variance) discriminates $\mathrm{La}-\mathrm{Sr}-\mathrm{Ce}-\mathrm{V}$ from $\mathrm{Co}-\mathrm{Cu}-\mathrm{Sc}-\mathrm{Ni}$ that reflects some

340 geochemical dependence to the parent rock.

\subsection{Factors of the ferricrete biochemical degradation}

345 the ferricrete result in the loosening of the ferruginous cements and their bioturbation by 
346 burrowing animals such as worms and termites. Termites microdivide the mineralogical

347 assemblages and transfer nutrients and clay-silts from the saprolite to the upper

348 ferruginous horizons and the topsoils (Eschenbrenner, 1986, 1987; Gleeson and Poulin,

349 1989; Tardy and Roquin, 1992; Thomas, 1994). Many topsoils of Central Africa are

350 formed, at least in part, from imported material from deeper horizons by termite activity

351 (De Heinzelin, 1955; De Ploey, 1964). The termite material may be spread at the ground

352 surface by erosion (Fig. 3b) that effectively contributed to the soil restoration and

353 hillslope forestation (Mando et al., 1996; Runge and Lammers, 2001), which are further

354 sustained by the nutrients transferred from the bottom to the top of the profiles

355 (Miedema et al., 1994; Berner and Berner, 1996). The forest biochemically degrades the

356 ferricrete transforming its main mineralogical constituents (Tardy and Roquin, 1992;

357 Birkeland, 1999). Notice that many ferruginous "stone lines" of the tropical forest

358 savanna transition areas may result from the combined termite activity and ferricrete

359 biophysical degradation (Eschenbrenner, 1986, 1987).

360 In spite of the lack of specific biogeochemical data, some interesting idea based on

361 field observations may be discussed before to be tested in future investigations. The

362 increasing biological activity generates bioturbation and aeration of the lateritic

363 weathering profiles by creating channels, chambers and pedotubules that improve the

364 hydrological properties of soils (drainage) and the plants development (Humphreys,

365 1994; Mando et al., 1996; Runge and Lammers, 2001). The digestion of the organic

366 matter by termites modifies the redox conditions of the vadoze zone. In the lateritic

367 profiles evolving under a forest cover the organic matter biodegradation may result in a

368 degassing of a mixture of carbon monoxide and methane. The occurrences of degassing

369 and water at the bottom of 10 to $15 \mathrm{~m}$ thick profiles may have a biogeochemical impact

370 on the geochemical and mineralogical patterns of the lateritic weathering profiles.

Beauvais, 2008 
371 Although the gases were not analytically identified, they were highly suspected by acid

372 smells owing to the organic matters decomposition, by experimenting burn rope (CO)

373 and observing termite activity $\left(\mathrm{CH}_{4}\right)$ at the transition between the saturated and

374 unsaturated zone of profiles (10 to 15 meter depth). Carbon monoxide derives from the

375 partial oxidation of organic matter as:

376

377

$$
\mathrm{CH}_{2} \mathrm{O}+0.5 \mathrm{O}=\mathrm{CO}+\mathrm{H}_{2} \mathrm{O}
$$

378

379 Methane result from the biodegradation of organic matter in termites' guts (Berner and

380 Berner, 1996; Mackenzie, 1998) according to the following reaction:

381

382

$$
\mathrm{CH}_{2} \mathrm{O}+\mathrm{H}_{2} \mathrm{O}=\mathrm{CH}_{4}+\mathrm{O}_{2}
$$

383

384 It results from (1) and (2) the global dissociation reaction of organic matter:

385

386

$$
2 \mathrm{CH}_{2} \mathrm{O}=\mathrm{CO}+\mathrm{CH}_{4}+0.5 \mathrm{O}_{2}
$$

387

388 That leads to carbon dioxide production with methane as:

389

390

$$
\mathrm{CO}+\mathrm{CH}_{4}+0.5 \mathrm{O}_{2}=\mathrm{CO}_{2}+\mathrm{CH}_{4}
$$

392 It would be certainly interesting to analytically characterize the organic species in

393 the degradation matrices and in the solutions draining the disaggregated ferricrete

394 profiles as well as to get $\mathrm{C}$ isotopic signatures of the organic matters, soil solutions, and

395 gaseous phases. For instance, the measure of ${ }^{13} \mathrm{C} /{ }^{12} \mathrm{C}$ ratios would be useful to 
396 distinguish bacterial from non-bacterial sources of methane (Conny and Currie, 1996).

397 However, the geochemical degradation of the ferricrete including the transformation of

398 its mineralogical constituents may be primarily controlled by the degree of hydration of

399 the profile (Tardy, 1997), and by the redox conditions change owing to the

400 biodegradation of organic matters producing $\mathrm{H}^{+}$protons (Berner and Berner, 1996).

\subsection{Mineralogical outcomes of the ferricrete biochemical degradation}

403

The increasing biological dynamics and soil moisture (pore water activity) therefore result in an increase of gibbsite and in a lesser part goethite with respect to kaolinite and hematite. Goethite content does not significantly increase (Table. 1), but hematite is partly dissolved under the combined effect of redox and hydration process.

The organic matter biodegradation (reaction 4) and hydration processes may effectively create the conditions of the disruption of the hematite - kaolinite mineral association according to the following reaction:

$$
\begin{aligned}
\mathrm{Fe}_{2} \mathrm{O}_{3} & +\mathrm{Si}_{2} \mathrm{Al}_{2} \mathrm{O}_{5}(\mathrm{OH})_{4}+\mathrm{CO}_{2}+\mathrm{CH}_{4}+\mathrm{O}_{2}+4 \mathrm{H}_{2} \mathrm{O}+3 \mathrm{H}^{+} \\
& =2 \mathrm{Al}(\mathrm{OH})_{3}+\mathrm{FeOOH}+2 \mathrm{HCOOH}+2 \mathrm{Si}(\mathrm{OH})_{4}+\mathrm{Fe}^{3+}
\end{aligned}
$$

The released Fe may be exported towards the lower parts of the profiles and

reincorporated in a newly formed ferricrete essentially composed of goethtite (Beauvais, 1999), according to local redox conditions also favorable to the formation of Ce and Mn-oxhyhydroxydes (Beauvais and Colin, 1993).

The matrices and ferruginous nodules of the Guenekoumba profile are a little more gibbsitic but less kaolinitic than those of the Finzani profile (Figs. 10a and 11a). Nodules and ferricretes of Finzani contain more kaolinite than those of Guenekoumba 
422 (Fig. 11a) but the same gibbsite quantities. According to Tardy (1997), the

423 transformation of kaolinite into gibssite is limited in quartz-rich matrices, while this

424 transformation is important in matrices impoverished in quartz. But our results show

425 that relatively high quantities of small size quartz in bioturbated matrices (Figs. 6c-d

426 and 10a) do not preclude the transformation of kaolinite into gibbsite (Figs. 6a-b and

427 11a). In tropical soils this transformation is driven by high water activity $\left(\left[\mathrm{H}_{2} \mathrm{O}\right]=1\right)$ in

428 large pores (Tardy, 1997). Gibbsite effectively derives from kaolinite according to

429 desilification and hydration processes that lead to a decrease of kaolinite in the matrices

430 compared with the contents measured in the ferricrete and nodules (Fig. 11a). However

431 in soils with similar physical chemical properties (porosity, water activity and Eh-pH

432 conditions), the presence of silicates as phengites and quartz maintains relatively high

433 amounts of $\mathrm{Si}, \mathrm{Al}$, and $(\mathrm{Ba}, \mathrm{K}, \mathrm{Mg})$ within the matrices (Table 2) that may limit the

434 transformation of kaolinite into gibbsite (Fig. 10a). This is the case of matrices of the

435 Finzani degradation profile (Fig. 11a) where the quantity of poorly weathered micas

436 inherited from the deeper horizons is higher than in the Guenekoumba profile.

437 Therefore, a part of the kaolinite may derive from the late weathering of micas if the

438 water activity in matrix pores is $\leq 0.9$; but hematite could remain stable (Trolard and

439 Tardy, 1987). However, it was previously shown that kaolinite deriving from micas is

440 large and well crystallized and could be a mineralogical tracer of the late ferricrete

441 degradation (Beauvais and Bertaux, 2002). Both micas and kaolinite may however

442 transform into gibbsite if the water activity $>0.9$ (Tardy, 1997), and the hematite is

443 dissolved and partly transformed into goethite (Trolard and Tardy, 1987).

\section{5. Conclusion}


447 In transitional humid tropical environments between savanna and rainforest, the

448 degradation of ferricrete previously composed of hematite and kaolinite results in the

449 development of a softer material relatively richer in gibbsite and in a lesser part in

450 goethite. The ferricrete degradation horizon is composed of chemically unsaturated

451 ferricrete relicts and ferruginous nodules embedded in a bioturbated micro-aggregated

452 clay ferruginous matrix. This matrix is also enriched in poorly weathered parent

453 minerals such as micas inherited from lower saprolite, and also with small size quartz

454 and heavy minerals, which may be biomechanically transferred by termites from the

455 lower horizons of the lateritic weathering profiles. The nutrient supplies by termites

456 may sustain the forest recrudescence on previous savanna areas implying the

457 biophysical dismantling and the geochemical degradation of the ferricrete. Such an

458 ecosystem may self-organize according to a positive feedback loop in that, the more

459 humid becomes the climate, the faster the forest grows in area enriched in nutrients

460 imported by termites, the more the ferricrete transforms into a micro-aggregated soil,

461 which sustains the forest development and therefore its destructive effect on the

462 ferricrete. The resulting hydration and biological processes lead to the biodegradation

463 and oxidation of organic matters modifying the redox conditions that also trigger the

464 ferricrete degradation. These processes result in the preferential dissolution of hematite,

465 and the transformation of kaolinite into gibbsite provide the moisture (water activity) be

466 sufficient that may also characterize the late "bauxitization" (Holocene) of previous

467 ferricrete profiles.

469 Acknowledgements - This is an IRD (UMR 161 CEREGE) contribution, which was

470 previously supported by the research program PIRAT (INSU-CNRS-ORSTOM). Two

471 anonymous reviewers are thanked for their helpful remarks and suggestions. 


\section{References}

474 Beauvais, A., 1991. Paléoclimats et dynamique d'un paysage cuirassé du Centrafrique.

475 Morphologie, Pétrologie et Géochimie. Ph. D. Thesis, University of Poitiers, France.

476 Beauvais, A., 1999. Geochemical balance of lateritization processes and climatic

477 signatures in weathering profiles overlain by ferricrete in Central Africa. Geochim.

$478 \quad$ Cosmochim. Acta 63, (23/24), 3939-3957.

479 Beauvais, A., Bertaux, J., 2002. In situ characterization and differentiation of kaolinites

480 in lateritic weathering profiles using infrared microspectoscopy. Clays Clay Miner.

$481 \quad 50 / 3,314-330$.

482 Beauvais, A., Colin, F., 1993. Formation and transformation processes of iron duricrust 483 systems in tropical humid environment. Chem. Geol. 106, 77-151.

484 Beauvais, A., Ritz, M., Parisot, J-C., Dukhan, M., Bantisimba, C., 1999. Analysis of 485 poorly stratified lateritic terrains overlying a granitic bedrock in West Africa, suing 486 2-D electrical resistivity tomography. Earth Planet. Sci. Letters 173, 413-424.

487 Beauvais, A., Roquin, C., 1996. Petrological differentiation patterns and geomorphic 488 distribution of ferricretes in Central Africa. Geoderma 73, 63-82.

489 Berner, E. K., Berner, R. A., 1996. Global environment, Water, Air, and Geochemical $490 \quad$ Cycles. Prentice Hall.

491 Birkeland, P.W., 1999. Soils and Geomorphology. Oxford University Press, New York.

492 Boski, T., Herbosch, A., 1990. Trace elements and their relation to the mineral phases in the 493 lateritic bauxites from southeast Guinea-Bissau. Chem. Geol. 82, 279-297.

494 Boulvert, Y., 1986. Carte phytogéographique de la République Centrafricaine à 1: 1.000.000.

495 feuille Ouest, feuille Est. ORSTOM, collection notice explicative, 104, Paris.

496 Boulvert, Y., 1996. Etude géomorphologique de la République Centrafricaine. Notice

497 explicative de la carte à 1/1 000 000. ORSTOM, Paris. 
498 Braun, J-J., Pagel, M., Muller, J-P., Bilong, P., Michard, A., Guillet, B., 1990. Cerium

499 anomalies in lateritic profiles. Geochim. Cosmochim. Acta 54, 781-795.

500 Brimhall, G. H., Lewis, C. J., Ford, C., Bratt, J., Taylor, G., Warin, O., 1991. Quantitative

501 geochemical approach to pedogenesis: importance of parent material reduction, volumetric

502 expansion, and eolian influx in lateritization. Geoderma 51, 1-4, 51-91.

503 Brown, D. J., Helmke, P. A., Clayton, M. K., 2003. Robust geochemical indices for redox and 504 weathering on a granitic laterite landscape in Central Uganda. Geochim. Cosmochim. Acta $505 \quad 67,2711-2723$.

506 Büdel, J., 1982. Climatic geomorphology. Princeton University Press, Princeton, New $507 \quad$ Jersey.

508 Butt, C.R.M., 1987. A basis for geochemical exploration models for tropical terrains.

$509 \quad$ Chem. Geol. 60, 5-16.

510 Colin, F., Alarcon, C., Vieillard, P., 1993. Zircon: an immobile index in soils ? Chem. Geol. $511 \quad 107,273-276$.

512 Conny, J. M., Currie, L. A., 1996. The isotopic characterization of methane, non-methane

513 hydrocarbons and formaldehyde in the troposphere. Atm. Environ. 30/4, 621-638.

514 De Heinzelin, J., 1955. Observations sur la génèse de nappe de gravats dans les sols

515 tropicaux. Publication de l'INEAC, série Scientifique, 64, Brussels.

516 De Ploey, J., 1964. Stone-lines and clayey-sandy mantles in lower Congo: their formation and

517 the effect of termites. In: Bouillon, A. (Ed.), Etudes sur les Termites Africains, Université

518 de Louvanium, Leopoldville, 399-414.

519 Donkin, M. J., Fey, M. V., 1991. Factor analysis of familiar properties of some Natal soils

$520 \quad$ with potential for afforestation. Geoderma 48, 3/4, 297-304.

521 Eschenbrenner, V., 1986. Contribution des termites à la microagrégation des sols tropicaux.

522 Cah. ORSTOM sér. Pédol. 22, 397-408. 
523 Eschenbrenner, V., 1987. Les glèbules des sols de Côte d'Ivoire. Thèse faculté Sciences,

$524 \quad$ Université de Bourgogne, France.

525 Eschenbrenner, V., Grandin, G., 1970. La sequence de cuirasses et ses différenciations entre 526 Agnibilékrou (Côte d'Ivoire) et Diébougou (Haute-Volta). Cah. ORSTOM, sér. Géol. II $527 \quad(2), 205-245$.

528 Gleeson, C.F., Poulin, R., 1989. Gold exploration in Niger using soils and termitaria. J. 529 Geochem. Explor. 31, 253-283.

530 Grandin, G., 1976. Aplanissements cuirassés et enrichissement des gisements de manganese 531 dans quelques regions d'Afrique de l’Ouest. Mém. ORSTOM 82, Paris.

532 Humphreys, G. S., 1994. Bioturbation, biofabrics and the biomanatle : an example from the 533 Sydney basin. In: Ringose-Voase, A.J., Humphreys, G.S. (Eds.), Soil micromorphology : 534 studies in management and genesis, , Developments in Soil Science 22, 421-436.

535 Lebart, L., Morineau, A., Fénélon, J.P., 1979. Traitement des données statistiques. 536 Dunod, Paris.

537 Leprun, J-C, 1979. Les cuirasses ferrugineuses des pays cristallins de l'Afrique

538 occidentale sèche- Genèse, transformations, dégradation. Mém. Sci. Géol., 539 Strasbourg, France.

540 Litaor, M. I., Dan, Y., Koyumdjisky, H., 1989. Factor analysis of a lithosequence in the 541 northeastern Samaria steppe (Israel). Geoderma 44, 1-15.

542 Mackenzie, F. T., 1998. Our changing planet. An introduction to earth system science 543 and global environmental change. Prentice Hall.

544 Mando, A., Stroosnijder, L., Brussard, L., 1996. Effects of termites on infiltration into $545 \quad$ crusted soil. Geoderma 74, 107-113.

546 Mazaltarim, D., 1989. Géochimie des cuirasses ferrugineuses et bauxitiques de l'Afrique de 547 l'Ouest et Centrale. Ph. D Thesis, University of Strasbourg, France. 
548 Michel, P., 1973. Les bassins des fleuves Sénégal et Gambie: étude géomorphologique. Mém.

$549 \quad$ ORSTOM 63, Paris.

550 Miedema, R., Brouwer, J., Geiger, S. C., Vandenbeldt, R. J., 1994. Variability in the growth

551 of Faidherbia albida near Niamey, Niger, Africa : micromorphological aspects of termite

552 activity. In: Ringose-Voase, A.J. Humphreys, G.S. (Eds.), Soil micromorphology : studies

553 in management and genesis, Developments in Soil Science 22, 411-419.

554 Millot, G., 1983. Planation of continents by intertropical weathering and pedogenetic

555 processes. In lateritisation processes, Melfi, A. J., Carvalho, A., Eds, Proceedings of

556 the II international Seminar on Lateritisation Processes, Sao Paulo, Brazil, 1982, pp.

$557 \quad 53-63$.

558 Nahon D., 1986. Evolution of iron crust in tropical landscapes. In: S.H. Colemans and

559 D.P. Dethier (Eds.), Rates of Chemical weathering of rocks and minerals, Chap. 9,

$560 \quad 169-191$.

561 Nahon D., 1991. Introduction of the petrology of soils and chemical weathering. John Wiley

$562 \quad \&$ Sons, New York.

563 Nahon D., Melfi A., Conte C. N., 1989. Présence d'un vieux système de cuirasses

564 ferrugineuses latéritiques en Amazonie du Sud- Sa transformation in situ en latosols

565 sous la forêt équatoriale actuelle. C. R. Acad. Sci., Paris, sér. II, 308, 755-760.

566 Novikoff A., 1974. L'altération des roches dans le massif du Chaillu (République

567 populaire du Congo). Formation et évolution des argiles en zone ferrallitique. Thèse

568 Sc., University of Strasbourg, France.

569 Roquin, C., Freyssinet, Ph., Zeegers, H., Tardy, Y., 1990. Element distribution patterns in

$570 \quad$ laterites of southern Mali: consequence for geochemical prospecting and mineral explora571 tion. Applied Geochem. 5, 303-315. 
572 Runge, J., 2002. Holocene landscape history and palaeohydrology evidenced by stable carbon

573 isotope $\delta^{13} \mathrm{C}$ analysis of alluvial sediments in the Mbari valley $\left(5^{\circ} \mathrm{N} / 23^{\circ} \mathrm{E}\right)$, Central

$574 \quad$ African Republic. Catena 48/1-2, 67-87.

575 Runge, J., Lammers, K., 2001. Bioturbation by termites and late quaternary landscape 576 evolution on the Mbomou plateau of the Central African Republic (CAR). In: van

577 Zinderen Bakker Sr., Heine K. (Eds.), Palaeoecology of Africa and of the surroundings $578 \quad$ Islands 27, 153-169.

579 Sillans, R., 1958. Les savanes de l'Afrique Centrale. Lechevalier, Paris.

580 Tardy, Y., 1997. Petrology of laterites and tropoical soils. Balkema, Amsterdam.

581 Tardy Y. and Nahon D., 1985. Geochemistry of laterites, stability of Al-goethite, Al-hematite 582 and $\mathrm{Fe}^{3+}$-kaolinite in bauxites and ferricretes : an approach to the mechanism of concretion 583 formation. Am. J. Sci. 285, 865-903.

584 Tardy, Y., Mazaltarim, D., Boeglin, J.L., Roquin, C., Pion, J.C., Paquet, H., Millot, G., 1988.

585 Lithodépendance et homogénéisation de la composition minéralogique et chimique des

586 cuirasses ferrugineuses latéritiques. C. R. Acad. Sci., Paris, sér. II, 307, 1715-1722.

587 Tardy, Y., Roquin, C., 1992. Geochemistry and evolution of lateritic landscapes. In: Martini,

588 I. P., Chesworth, W. (Eds.), Weathering, Soils \& Paleosols, Developments in Earth

$589 \quad$ Surface Processes 2, 407-471.

590 Tardy, Y., Roquin, C., 1998. Dérive des continents, Paléoclimats et altérations tropicales.

$591 \quad$ BRGM editions, Orléans, France.

592 Thomas, M. F., 1994. Geomorphology in the tropics. A study of weathering and denudation in 593 low latitudes. John Wiley \& Sons.

594 Trolard, F., Tardy, Y., 1987. The stabilities of gibbsite, boehmite, aluminous goethites and 595 aluminous hematites in bauxites, ferricretes and laterites as a function of water activity, 596 temperature and particle size. Geochim. Cosmochim. Acta 51/4, 945-957. 


\section{$598 \quad$ Figures caption}

599

600 Figure 1. (a) Location of the study area in Central African Republic (CAR). The black

601

602

603

604

605

606

607

608

609

610

611

612

613

614

615

616

617

618

619

620

621

622

623

624

625 rectangle represents the previous mapped land area (Beauvais and Roquin, 1996; Beauvais, 1999). (b) Geomorphic distribution of the different forms of ferricrete. The black square is for the location of the disaggregated-ferricrete profile at Guénékoumba.

(c) Geomorphological transect across c shown in (b).

Figure 2. (a) Sketch of a typical undisturbed profile, (b) Macroscopic patterns of the disaggregated ferricrete, (c) and (d) disaggregated ferricrete profiles of Guenekoumba and Finzani, respectively. The grey and black squares represent the analyzed samples.

Figure 3. (a) Gently sloping surface (bare hillslope) colonized by termite mounds, (b)

Detail of the mounds at the transition between the grassy and forested hillslope (the size of the foreground ferricrete block is $0.5-0.6 \mathrm{~m})$.

Figure 4. Transformation of a red-black hematite-kaolinite nodule into yellow goethite, (a) Polarised optical microscope view, (b) Scanning electron microscope view (Go $=$ goethite crystals developing perpendicular to the nodule edge; $\mathrm{kHe}=$ kaolinite-hematite core of the nodule).

Figure 5. Transformation of kaolinite into gibbsite in a nodule, (a) Polarised optical microscope view. (b) Scanning electron microscope view. ( $K=$ kaolinite; $G=$ Gibbsite).

Figure 6. Scanning electron micrographs of the bioturbated micro-aggregated clay ferruginous matrix. (a) Microcrystalline newly formed gibbsite, (b) detail of (a), (c) relict quartz grain and (d) relict quartz grain with dissolution-crystallization figures. ( $\mathrm{kHe}=$ kaolinite-hematite; $\mathrm{G}=$ gibbsite; $\mathrm{Q}=$ quartz). 
626

631

636

641

645

627 Figure 7. Geochemical comparison between undisturbed ferricrete profile (grey) and

628 the disaggregated ferricrete horizon (black) of Guenekoumba, (a) Fe vs. Sc, (b) Fe vs.

$629 \mathrm{Zr}$, (c) Si vs. Zr, and (d) Ti vs. Zr, (the dashed line represents the relative accumulation

$630 \mathrm{and} /$ or depletion of chemical elements).

632 Figure 8. Geochemical differentiation pattern of the components in the undisturbed and

633 disaggregated profiles of Guenekoumba by the factor score diagram Fs1 vs. Fs2, (see

634 the table 1 for the factor loadings, and the figure 7 for the labels explanation). (Af=

635 advancing ferruginization; $\mathrm{Fd}=$ ferricrete degradation).

637 Figure 9. Geochemical differentiation pattern of the degradation components in the

638 disaggregated ferricrete horizons of Guenekoumba (black) and Finzani (grey) by the

639 factor score diagram Fs1 vs. Fs2, (see the table 3 for the factor loadings, and the figure

6407 for the labels explanation).

642 Figure 10. Comparison between each disaggregated ferricrete profile, (a) quartz content

$643 v$ s. ratio RKGi in the degradation matrices $(\mathrm{RKGi}=100 *$ kaolinite $/$ kaolinite +

644 gibbsite), (b) Ti vs. Zr (see Figures 7 and 9 for labels explanation).

646 Figure 11. Comparison between the two disaggregated ferricrete profile (a) kaolinite vs.

647 gibbsite contents, (b) Fe vs. $\mathrm{Zr}$ (see Figures 7 and 9 for labels explanation) 


\section{Tables caption}

650

651 Table 1. Correlation of chemical elements and minerals with each orthogonal

652 factorial axis defined by the Principal Component Analysis for the undisturbed

653 and disaggregated ferricrete profiles $(\sigma \%=\%$ of explained variance; loading

654 values are given in parentheses)

655

656 Table 2. Mean chemical and mineralogical compositions of the ferricrete

657 degradation components $(N=$ number of samples; $\mathrm{m}=$ mean; $\sqrt{ } \boldsymbol{\sigma}=$ standard

658 deviation; wt. $=$ weight; $\mathrm{LOI}=$ lost on ignition $\left(1000^{\circ} \mathrm{C}\right) ; \mathrm{RHG}=100 *$ hematite $/$

659 hematite + goethite; RKGi $=100$ * kaolinite / kaolinite + gibbsite).

660

661 Table 3. Correlation of chemical elements and minerals with each orthogonal

662 factorial axis defined by the Principal Component Analysis for the two

663 disaggregated ferricrete profiles $(\sigma \%=\%$ of explained variance; loading values

664 are given in parentheses)

666 

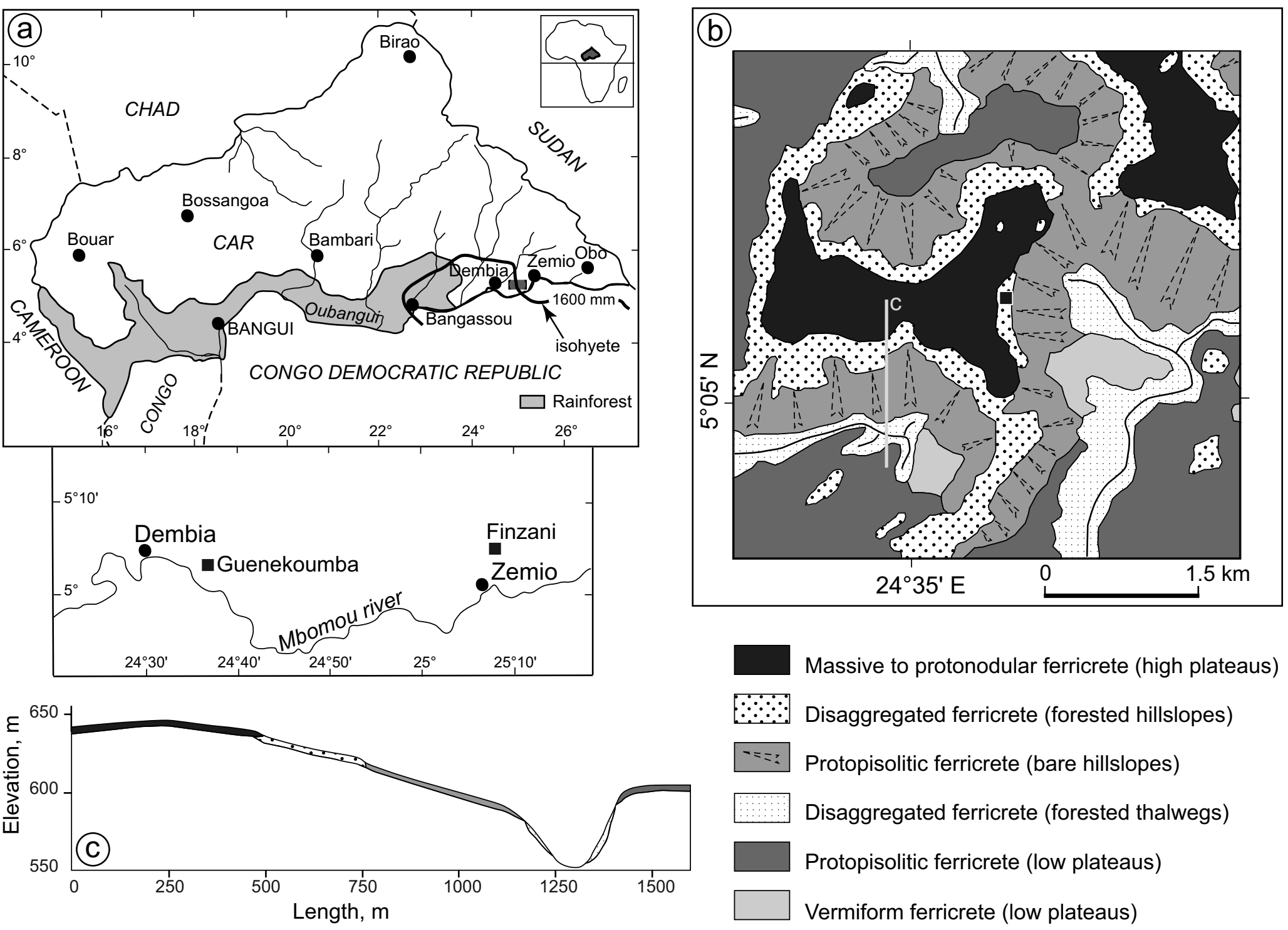

Fig. 1

Massive to protonodular ferricrete (high plateaus)

Disaggregated ferricrete (forested hillslopes)

Protopisolitic ferricrete (bare hillslopes)

Disaggregated ferricrete (forested thalwegs)

Protopisolitic ferricrete (low plateaus)

Vermiform ferricrete (low plateaus) 

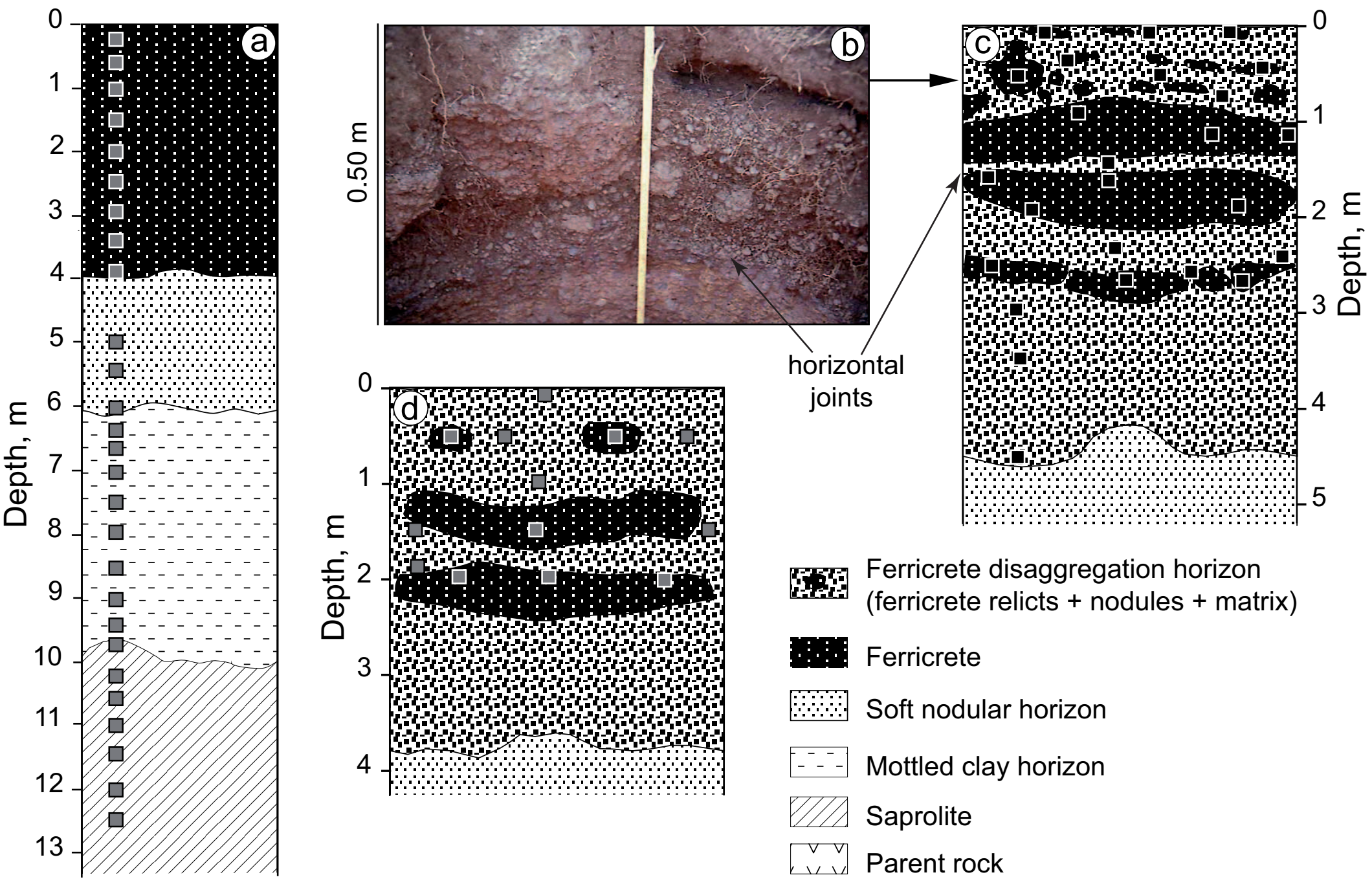

Fig. 2 
Figure

Click here to download high resolution image

(a)
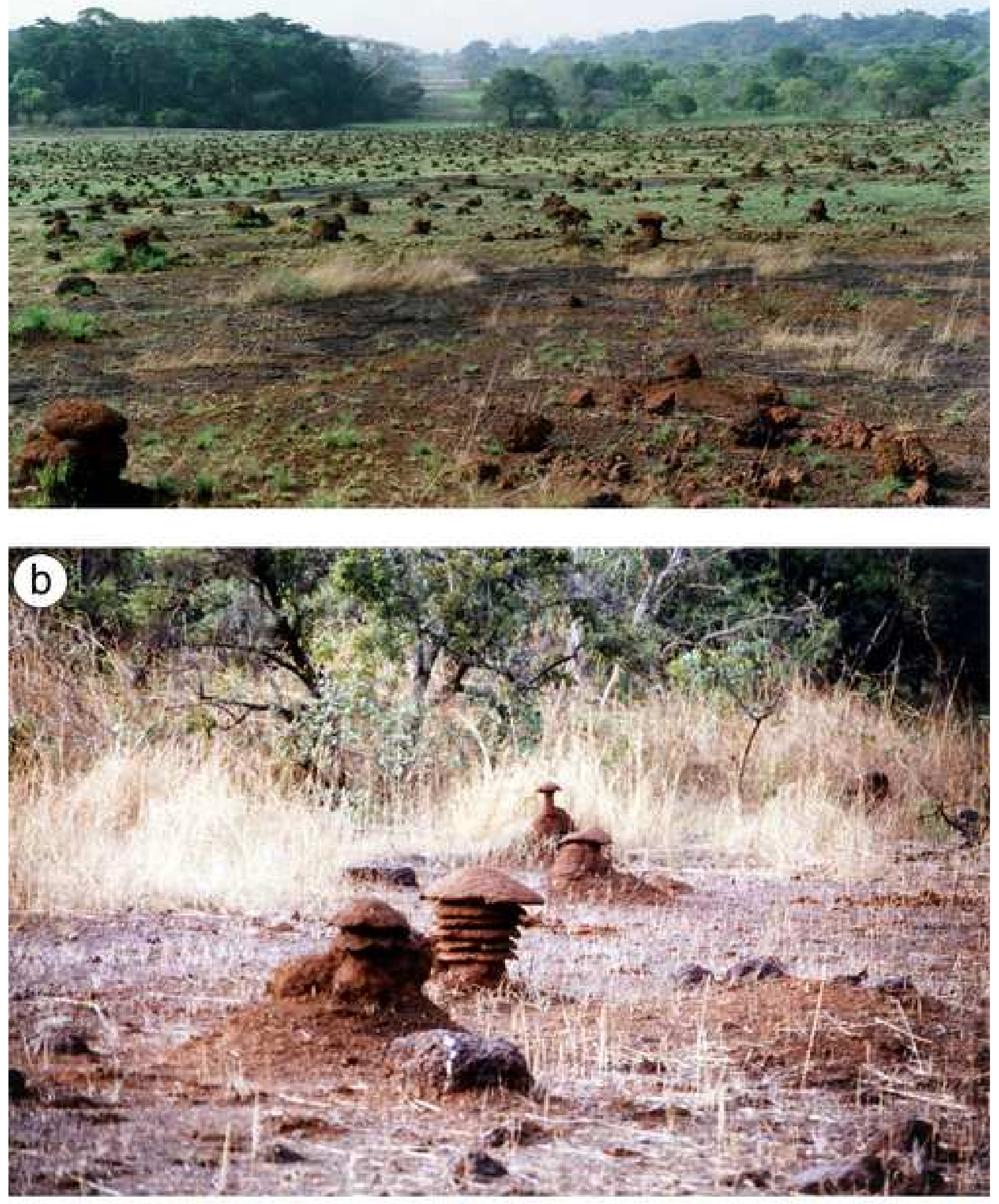

Fig. 3 
Click here to download high resolution image
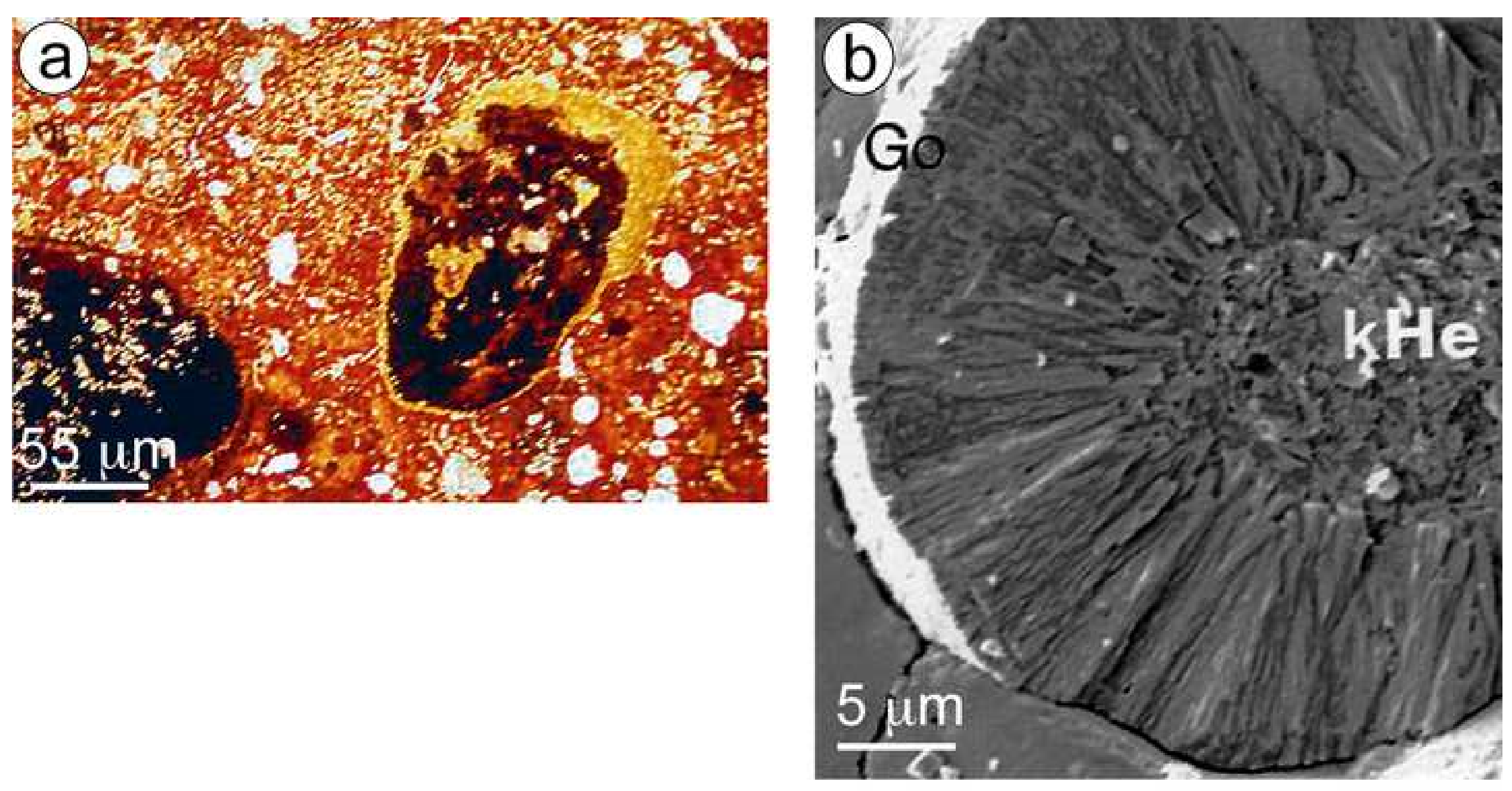

Fig. 4

Beauvais, 2008 


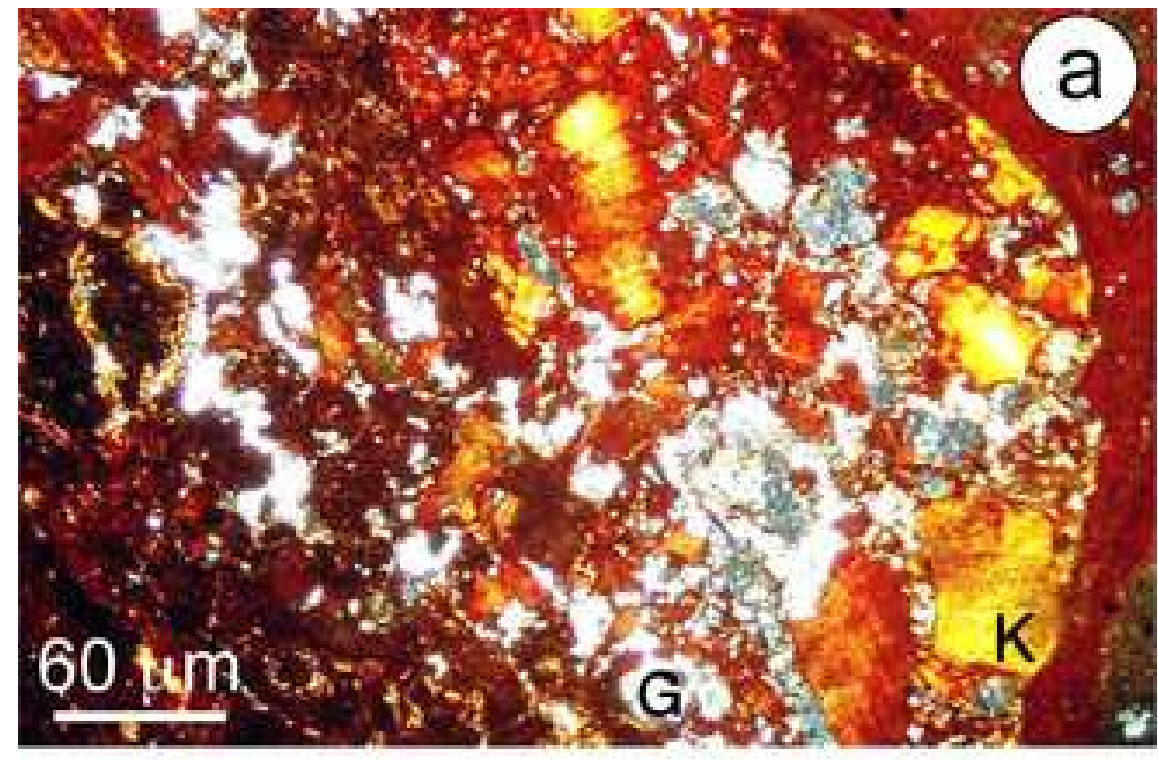

Fig. 5

Beauvais, 2008

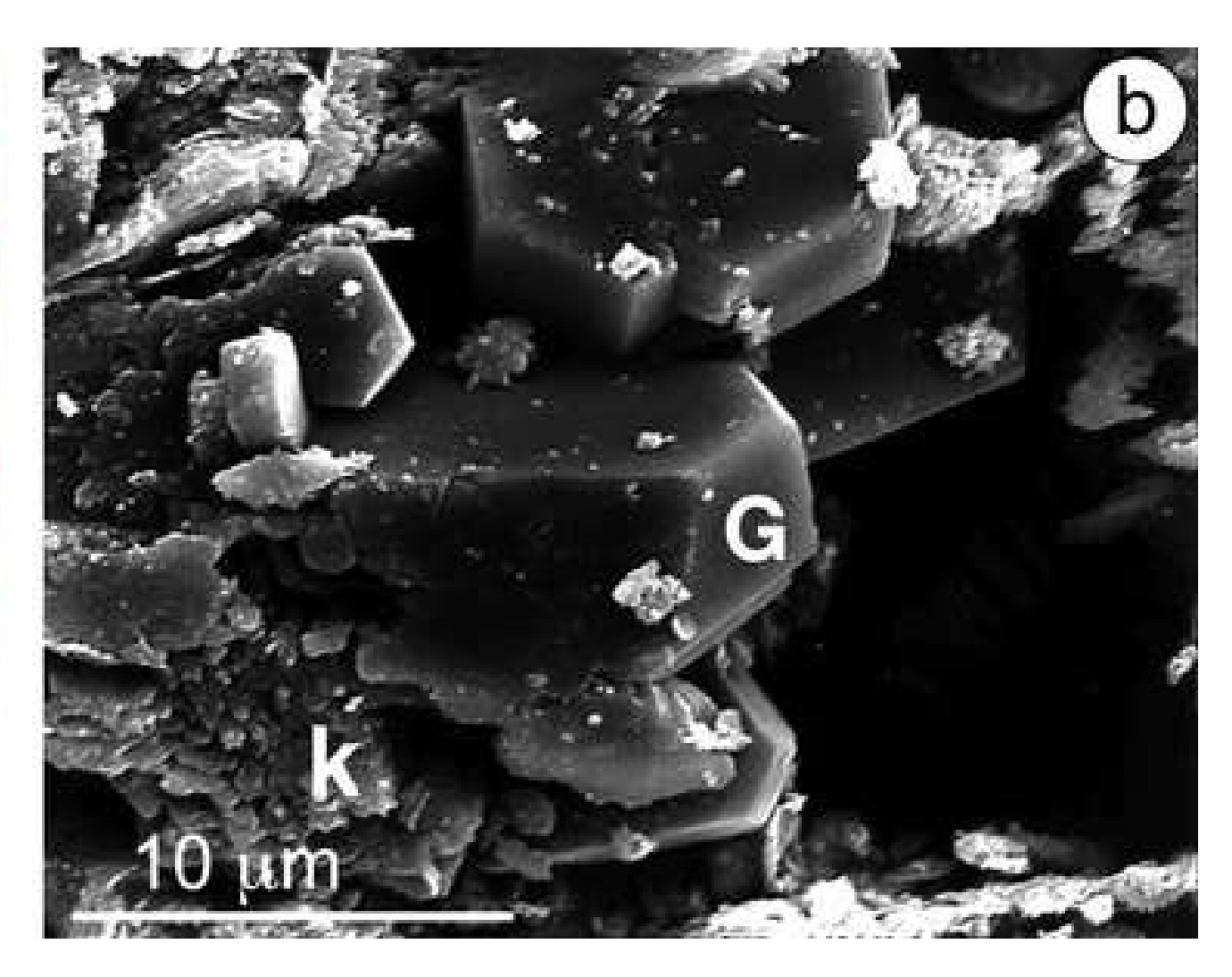


Click here to download high resolution image
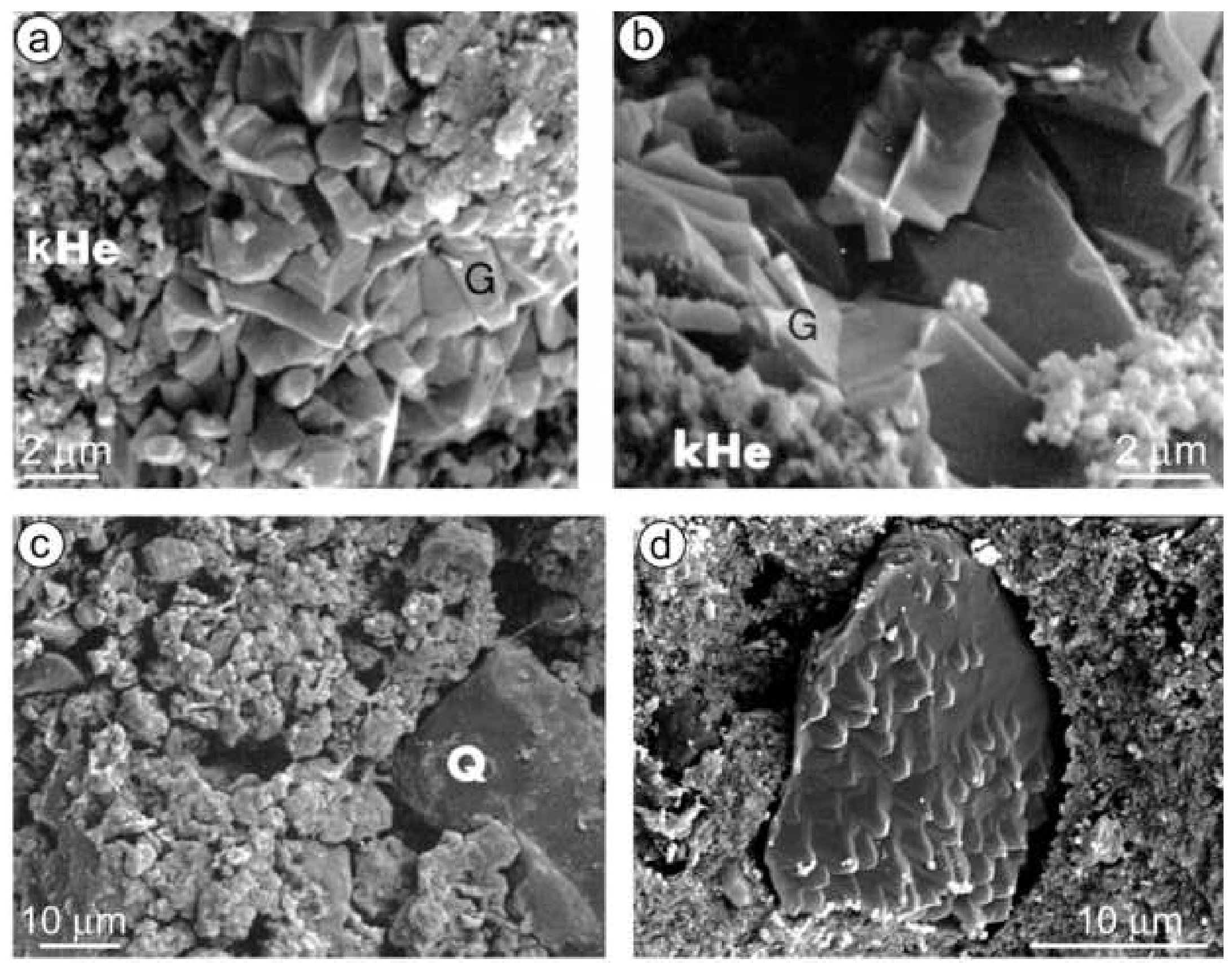

Fig. 6

Beauvais, 2008 


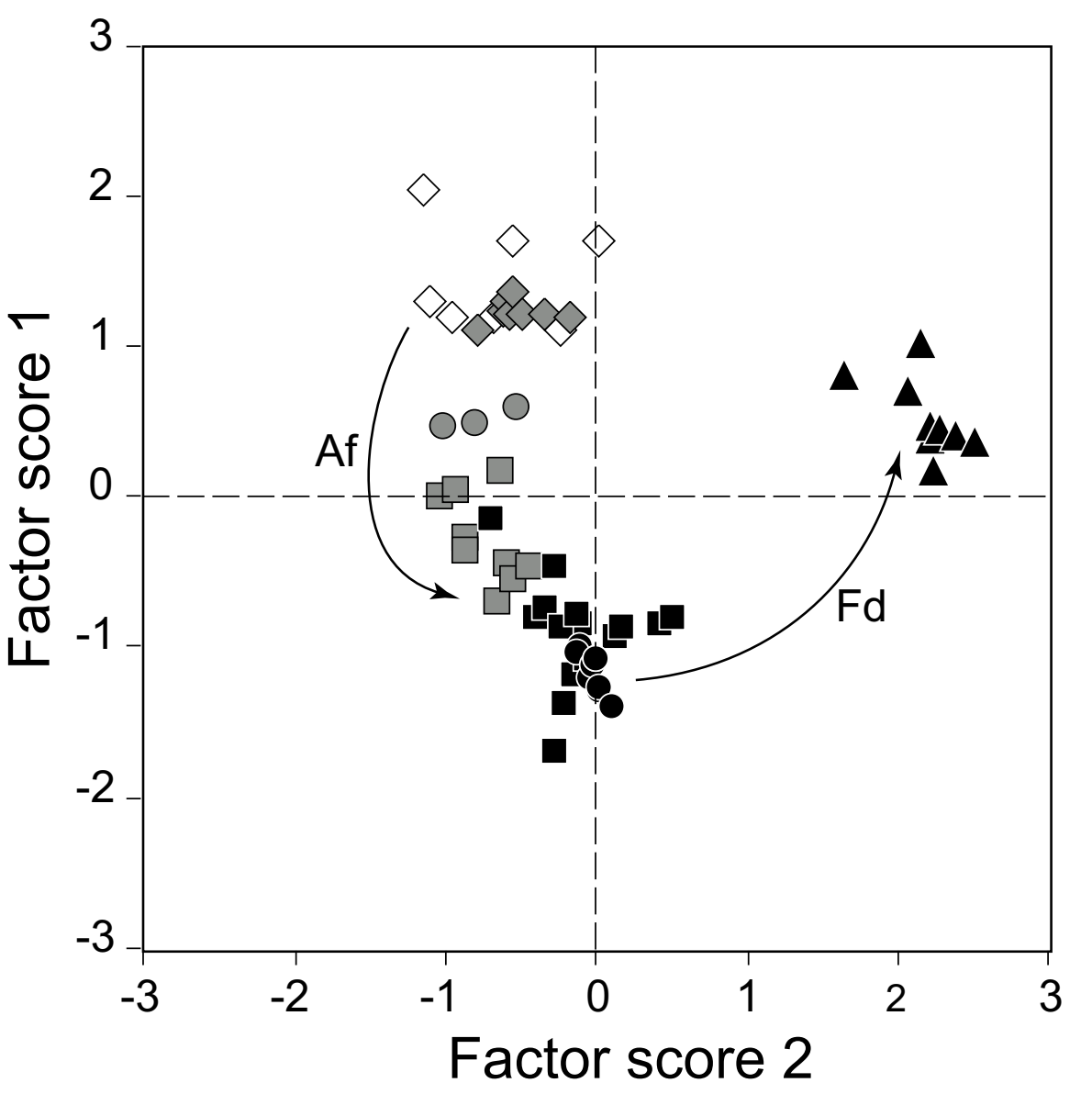

Fig. 8

$$
\text { Deauvals, ¿vUo }
$$

Beauvais, 2008 

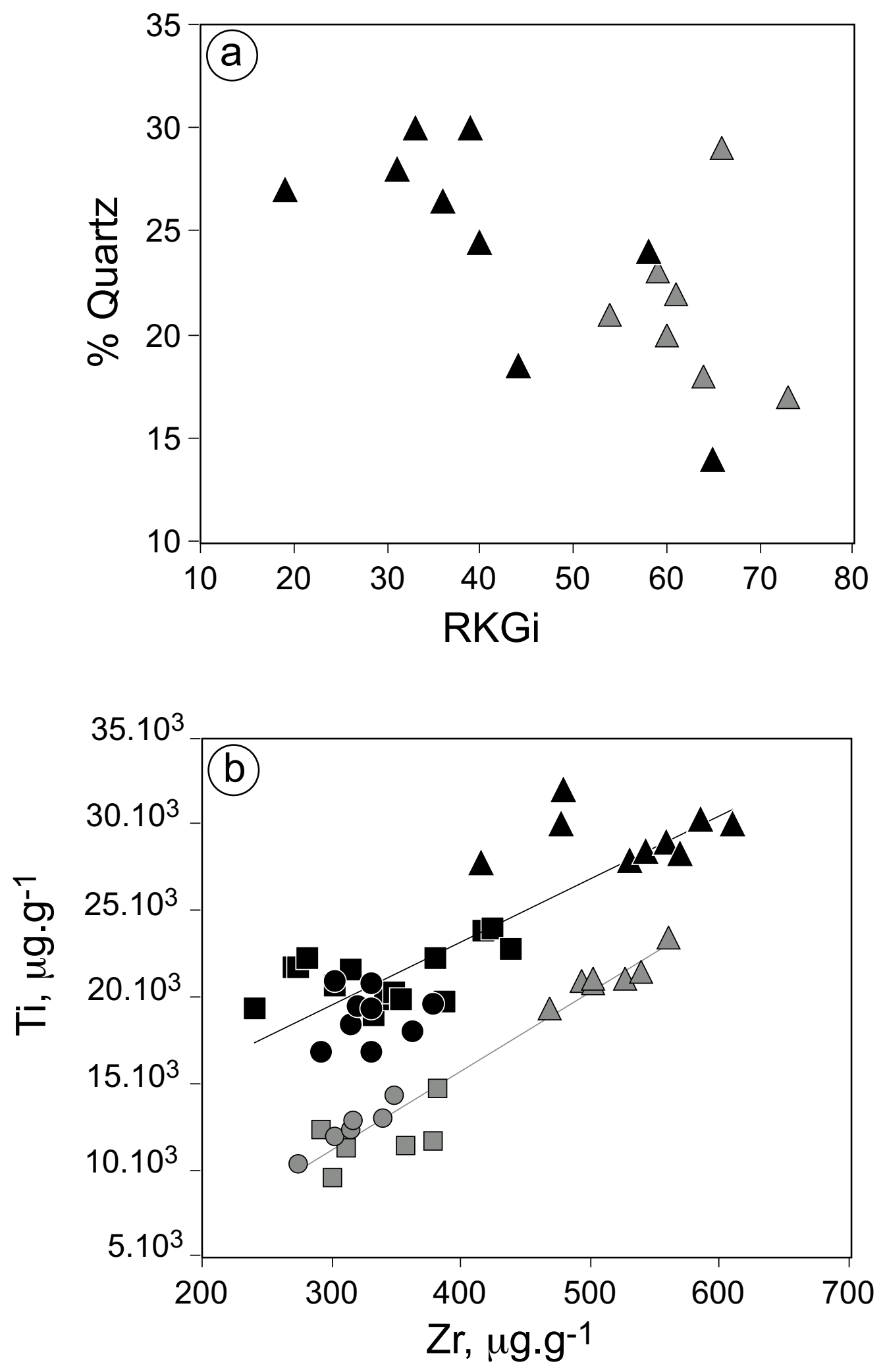

Fig. 10 

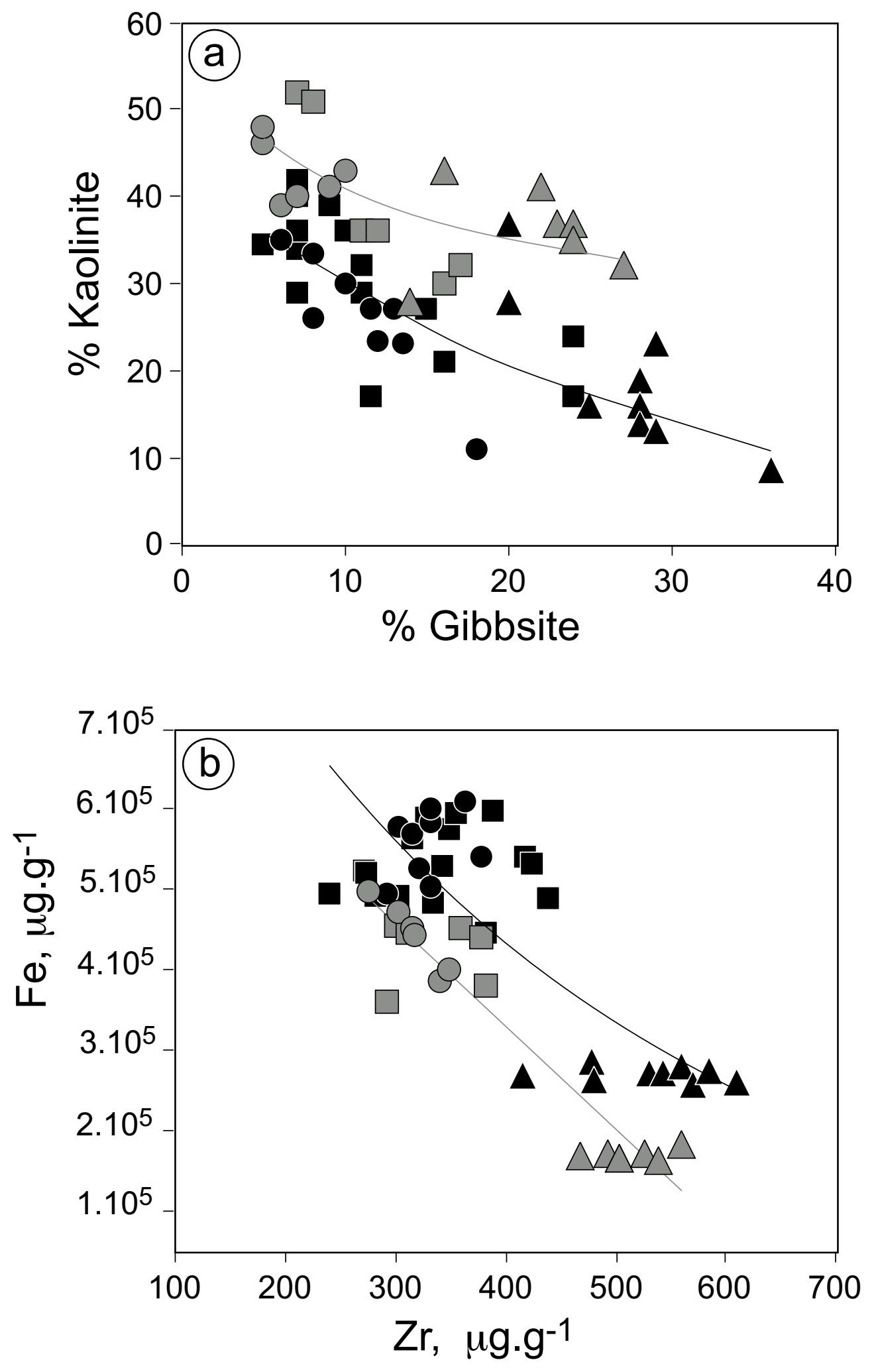

Fig. 11 


\begin{tabular}{|c|c|c|c|}
\hline $\begin{array}{c}\text { Factorial } \\
\text { Axis }\end{array}$ & $\sigma \%$ & Positive loading & Negative loading \\
\hline & & $\mathrm{Mn}_{3} \mathrm{O}_{4}(0.87) \mathrm{TiO}_{2}(0.81)$ & Hematite (0.94) \\
\hline & & $\mathrm{Al}_{2} \mathrm{O}_{3}(0.76) \mathrm{Y}(0.71)$ & $\mathrm{Fe}_{2} \mathrm{O}_{3}(0.81)$ \\
\hline \multirow[t]{3}{*}{$\mathrm{F} 1$} & 37.3 & $\mathrm{Ni}(0.71) \mathrm{Zn}(0.71) \mathrm{Sc}(0.66)$ & $\mathrm{Cr}(0.76) \mathrm{P}_{2} \mathrm{O}_{5}(0.75)$ \\
\hline & & Goethite (0.60) $\mathrm{SiO}_{2}(0.53)$ & $\mathrm{La}(0.57) \mathrm{V}(0.56)$ \\
\hline & & Kaolinite (0.52) $\mathrm{Cu}(0.50)$ & $\operatorname{Sr}(0.56)$ \\
\hline \multirow[t]{4}{*}{$\mathrm{F} 2$} & 23.6 & Quartz (0.93) Nb (0.89) & V (0.66) Sc (0.65) \\
\hline & & $\mathrm{Zr}(0.87) \mathrm{MgO}(0.73)$ & Goethite $(0.57)$ \\
\hline & & $\mathrm{Yb}(0.71) \mathrm{SiO}_{2}(0.63)$ & $\mathrm{Cu}(0.53) \mathrm{Fe}_{2} \mathrm{O}_{3}(0.48)$ \\
\hline & & Gibbsite (0.52) Y (0.52) & Kaolinite (0.43) \\
\hline \multirow[t]{2}{*}{ F3 } & 7.2 & Gibbsite (0.76) & Kaolinite (0.66) \\
\hline & & & $\mathrm{SiO}_{2}(0.47)$ \\
\hline $\mathrm{F} 4$ & 7.1 & $\begin{array}{l}\mathrm{Ce}(0.80) \mathrm{Ba}(0.77) \mathrm{Sr}(0.76) \\
\mathrm{La}(0.69)\end{array}$ & \\
\hline
\end{tabular}

Table 1. 


\begin{tabular}{|c|c|c|c|c|c|c|c|c|c|c|c|c|}
\hline \multirow{4}{*}{$\begin{array}{l}\text { Location: } \\
\text { Facies: } \\
\quad N:\end{array}$} & \multicolumn{6}{|c|}{ Guenekoumba profile } & \multicolumn{6}{|c|}{ Finzani profile } \\
\hline & \multirow{2}{*}{\multicolumn{2}{|c|}{$\begin{array}{c}\text { Ferricrete } \\
15 \\
\end{array}$}} & \multirow{2}{*}{\multicolumn{2}{|c|}{$\begin{array}{c}\text { Nodules } \\
9\end{array}$}} & \multirow{2}{*}{\multicolumn{2}{|c|}{$\begin{array}{c}\text { Matrices } \\
9 \\
\end{array}$}} & \multirow{2}{*}{\multicolumn{2}{|c|}{$\begin{array}{c}\text { Ferricrete } \\
6 \\
\end{array}$}} & \multirow{2}{*}{\multicolumn{2}{|c|}{$\begin{array}{c}\text { Nodules } \\
6 \\
\end{array}$}} & \multirow{2}{*}{\multicolumn{2}{|c|}{$\begin{array}{c}\text { Matrices } \\
7 \\
\end{array}$}} \\
\hline & & & & & & & & & & & & \\
\hline & $\mathrm{m}$ & $\sqrt{\sigma}$ & $\mathrm{m}$ & $\sqrt{\sigma}$ & $\mathrm{m}$ & $\sqrt{\sigma}$ & $\mathrm{m}$ & $\sqrt{\sigma}$ & $\mathrm{m}$ & $\sqrt{\sigma}$ & $\mathrm{m}$ & $\sqrt{\sigma}$ \\
\hline $\mathrm{SiO}_{2}$ wt. $\%$ & 14.89 & 3.35 & 15.17 & 3.11 & 32.83 & 3.15 & 21.73 & 3.94 & 22.75 & 2.4 & 37.87 & 1.52 \\
\hline $\mathrm{Al}_{2} \mathrm{O}_{3}$ & 19.21 & 2.44 & 17.27 & 1.15 & 24.53 & 1.62 & 23.47 & 1.63 & 21.93 & 2.2 & 29.67 & 1.15 \\
\hline $\mathrm{Fe}_{2} \mathrm{O}_{3}$ & 52.55 & 4.38 & 55.6 & 4.16 & 27.03 & 0.91 & 42.27 & 4.06 & 44.2 & 4.2 & 17.03 & 0.67 \\
\hline $\mathrm{Mn}_{3} \mathrm{O}_{4}$ & 0.06 & 0.02 & 0.04 & 0.01 & 0.09 & 0.02 & 0.02 & 0.01 & 0.03 & 0 & 0.05 & 0.02 \\
\hline $\mathrm{MgO}$ & 0.03 & 0.01 & 0.04 & 0.01 & 0.17 & 0.07 & 0.23 & 0.14 & 0.22 & 0.02 & 0.37 & 0.02 \\
\hline $\mathrm{K}_{2} \mathrm{O}$ & & & & & 0.11 & 0.02 & 0.61 & 0.55 & 0.46 & 0.06 & 0.35 & 0.08 \\
\hline $\mathrm{TiO}_{2}$ & 2.12 & 0.15 & 1.89 & 0.15 & 2.93 & 0.14 & 1.18 & 0.17 & 1.25 & 0.12 & 2.12 & 0.12 \\
\hline $\mathrm{P}_{2} \mathrm{O}_{5}$ & 0.39 & 0.06 & 0.38 & 0.05 & 0.25 & 0.04 & 0.19 & 0.03 & 0.19 & 0.01 & 0.18 & 0.02 \\
\hline LOI & 10.11 & 1.39 & 9.27 & 0.95 & 11.63 & 1.45 & 10.65 & 0.99 & 9.11 & 1.02 & 12.85 & 0.35 \\
\hline Sr ppm & 39 & 32 & 48 & 9 & 18 & 5 & 34 & 20 & 35 & 7 & 21 & 2 \\
\hline $\mathrm{Ba}$ & 32 & 24 & 51 & 14 & 40 & 7 & 223 & 179 & 157 & 19 & 95 & 12 \\
\hline $\mathrm{V}$ & 1369 & 280 & 1298 & 66 & 634 & 29 & 827 & 202 & 757 & 69 & 344 & 14 \\
\hline $\mathrm{Ni}$ & 47 & 19 & 36 & 6 & 78 & 23 & 35 & 10 & 51 & 6 & 79 & 21 \\
\hline $\mathrm{Co}$ & 13 & 5 & 11 & 2 & 13 & 4 & 9 & 8 & 16 & 3 & 20 & 4 \\
\hline $\mathrm{Cr}$ & 340 & 142 & 426 & 117 & 155 & 20 & 403 & 157 & 414 & 79 & 91 & 1 \\
\hline $\mathrm{Zn}$ & 52 & 19 & 50 & 5 & 62 & 16 & 34 & 14 & 40 & 8 & 40 & 8 \\
\hline $\mathrm{Cu}$ & 133 & 64 & 121 & 19 & 116 & 29 & 58 & 9 & 75 & 5 & 89 & 5 \\
\hline $\mathrm{Sc}$ & 42 & 6 & 46 & 6 & 37 & 5 & 36 & 3 & 37 & 1 & 40 & 2 \\
\hline $\mathrm{Y}$ & 8 & 2 & 8 & 1 & 23 & 2 & 12 & 2 & 12 & 3 & 31 & 2 \\
\hline $\mathrm{Zr}$ & 341 & 60 & 329 & 27 & 530 & 61 & 337 & 40 & 316 & 26 & 513 & 31 \\
\hline $\mathrm{La}$ & 47 & 39 & 51 & 12 & 23 & 5 & 34 & 12 & 39 & 6 & 33 & 5 \\
\hline $\mathrm{Ce}$ & 114 & 80 & 99 & 27 & 126 & 20 & 62 & 33 & 65 & 18 & 107 & 11 \\
\hline $\mathrm{Yb}$ & 1 & 0 & 1 & 0 & 3 & 0 & 2 & 0 & 2 & 0.5 & 4 & 0 \\
\hline $\mathrm{Nb}$ & 18 & 4 & 19 & 2 & 36 & 3 & 16 & 2 & 14 & 3 & 33 & 4 \\
\hline$\%$ Quartz & 1 & 1 & 3 & 3 & 25 & 5 & 3 & 2 & 3 & 1 & 22 & 4 \\
\hline Kaolinite & 31 & 8 & 27 & 7 & 19 & 9 & 40 & 10 & 44 & 3 & 38 & 5 \\
\hline Hematite & 41 & 6 & 45 & 5 & 17 & 1 & 33 & 6 & 37 & 4 & 9 & 1 \\
\hline Goethite & 16 & 6 & 14 & 3 & 12 & 1 & 12 & 3 & 8 & 1 & 9 & 1 \\
\hline Gibbsite & 11 & 6 & 11 & 4 & 27 & 5 & 12 & 4 & 8 & 2 & 22 & 5 \\
\hline RHG & 72 & 10 & 76 & 6 & 57 & 4 & 73 & 8 & 82 & 3 & 52 & 3 \\
\hline RKGi & 72 & 14 & 71 & 14 & 41 & 14 & 76 & 10 & 86 & 4 & 63 & 6 \\
\hline
\end{tabular}

Table 2. 


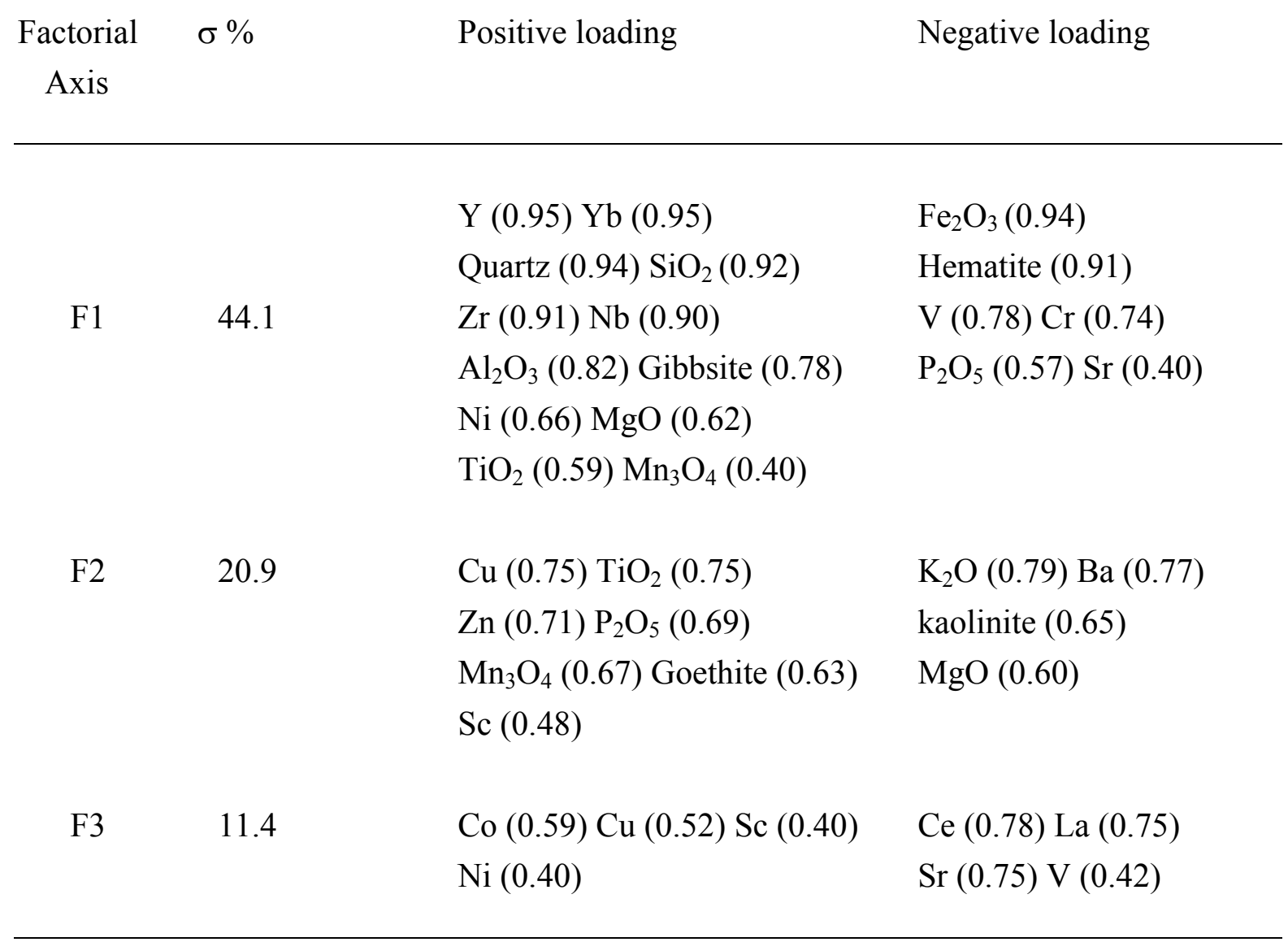

Table 3. 